Article

\title{
Millennium Development Goals and the Protection of Displaced and Refugee Women and Girls
}

\author{
Susan M. Akram
}

School of Law, Boston University, 675 Commonwealth Avenue, Suite 1244, Boston, MA 02215 , USA; E-Mail: smakram@bu.edu; Tel.: +1-617-353-3148

Received: 1 July 2013; in revised form: 6 August 2013 / Accepted: 19 August 2013 /

Published: 4 September 2013

\begin{abstract}
The international protection regime of refugee, stateless and displaced women and girls has significant deficiencies. As refugees and displaced persons, women and girls experience unique challenges. They suffer abuse disproportionately as women through rape, human trafficking, and female genital mutilation. Women and girl refugees face greater challenges and risks to safety at every stage of displacement: in refugee camps, in urban spaces, in transit to safe haven, and in the process of obtaining legal status. They are frequently at the mercy of male family members in making claims to refugee and asylum status, as females are often unable to obtain necessary documentation and navigate barriers to the asylum process that uniquely disfavor women's claims. This paper argues that the UN must expand the scope of the Millennium Development Goals to specifically include state responsibility towards refugees and displaced persons in their territories, without regard to their legal status. Until the international regime designed to protect refugees and displaced persons closes the gaps in addressing female refugees and displaced persons' unique vulnerabilities, the UN's Millennium Development Goals should be reoriented to include state responsibility to meet these deficiencies.
\end{abstract}

Keywords: refugee women; refugee girls; displaced; Millennium Development Goals (MDGs); rape; female genital mutilation (FGM)

\section{Introduction}

In September of 2000, the United Nations (“UN") established eight Millennium Development Goals ("MDGs") for the international community to meet by 2015. These MDGs are to: (1) eradicate extreme poverty and hunger; (2) achieve universal primary education; (3) promote gender equality and 
empower women; (4) reduce child mortality; (5) improve maternal health; (6) combat HIV/AIDS, malaria and other diseases; (7) ensure environmental sustainability; and (8) initiate a global partnership for development [1]. The goals are directed at states' responsibilities towards their citizens or residents in their territories. However, the MDGs leave out millions of people who are neither citizens nor residents of the states in which they find themselves - refugees and forcibly displaced persons - and within that population, the most vulnerable are women and girls. This essay addresses some of the consequences for female refugees and displaced women who are left out of critical millennium goals. The essay focuses on only three of the MDGs - 1, 3, and 8-in the context of the state of today's women and girl refugees and displaced persons [2]. The essay highlights the severe gap between the reality faced by female refugees and the aspirations behind these three MDGs. For example, MDG 1, which aims to ensure the eradication of extreme poverty and hunger, is unattainable in an environment in which women refugees do not have recognized legal status to allow them to seek employment in their countries of refuge. Lack of legal status also severely affects the promise of equality and female empowerment of MDG 3, which appears almost inapplicable to refugee girls and women. So, too, the commitment of a global partnership envisioned by MDG 8 , has been turned on its head. Global partnership, which in refugee parlance is international "burden-sharing," has been turned into "burden-shifting," with the poorest countries bearing the heaviest burden of both development and refugee assistance.

This paper argues that the UN must expand the scope of the MDGs to specifically include state responsibility towards refugees, stateless and other forcibly displaced persons in their territories, without regard to their legal status. Without serious attention to the legal and political deficiencies in the international regime of refugees and displaced persons, the UN's MDGs remain unattainable for millions of the world's most vulnerable women and girls. In fact, the promise of protection under the significant international and regional rights instruments for refugees is ephemeral for the vast majority of refugee women and girls today, but, if expansively interpreted, the MDGs may well be critical to closing some of the gaps. The essay ends with calling for a re-thinking of the scope of the MDGs to require state responsibility for fulfillment of the goals to extend to all refugees, forcibly displaced and stateless persons found on the territory of each state. The UN's claimed achievements on the MDGs cannot be credited if millions of the world's most vulnerable persons are left outside of their reach.

\section{The Scope and Consequences of Forced Displacement}

Before examining the particular consequences of forced displacement for women refugees, some statistics on refugees and forcibly displaced persons in general are warranted. At the end of 2012, the United Nations High Commissioner for Refugees ("UNHCR") [3] concluded that there were 45.2 million forcibly displaced people worldwide, the highest number since 1994 [4].

Forcible displacement is a complex phenomenon, encompassing persons fleeing their homes or states of origin against their will for many, and often multiple, reasons. These include armed conflict, persecution on various grounds, human trafficking, threats from organized crime, or environmental disasters [5]. Women suffer threats to their personal safety and dignity that lead to flight from their homes for additional reasons than do men, or suffer harm from those threats disproportionately from men. The consequences of forced displacement are similar for all victims in one aspect: they no longer 
receive protection as a matter of fact or law from their home states. However, the causes of displacement determine the level of substitute protection forcibly displaced persons can obtain from the international community, and thus the definition of their status under international law determines where in the hierarchy of protection priorities they are placed. Refugees are the most highly-regulated of the legal regimes for the forcibly displaced, with a widely ratified treaty in place for over 60 years, the Convention Relating to the Status of Refugees of 1951 ("Refugee Convention") [6]. The Refugee Convention has a UN agency, the United Nations High Commissioner for Refugees ("UNHCR"), dedicated to monitoring and implementing its terms and monitoring state compliance. UNHCR also has an independent mandate to provide humanitarian assistance and protection needs of the forcibly displaced, whether or not they fall under the precise refugee definitions of the Convention itself. Stateless persons also fall under a treaty regime, the 1954 Convention on the Status of Stateless Persons [7]. Stateless persons have additional protections under the more recent Convention on the Reduction of Statelessness (1961), but this is not a widely ratified treaty, with states parties primarily amongst the European states [7]. The UNHCR is also mandated with monitoring state obligations towards and the rights of stateless persons [8,9]. Forcibly displaced persons who do not meet the definition of refugees or stateless persons might fall into the categories of victims of human trafficking or the internally displaced, but these have weak or non-existent treaty protections, and fall far below refugees and stateless persons in the hierarchy of international concern.

Unfortunately, the protections for refugees and stateless persons - though the strongest available for forcibly displaced persons - have serious deficiencies in interpretation and application, leaving many deserving refugees outside meaningful international protection. The refugee and stateless persons regime addresses fewer and fewer of the victims of forced displacement. Over the ten year period from 2001-2011, the number of persons falling strictly within the definition of the Refugee Convention has decreased while populations of concern, or non-Refugee Convention-defined displaced persons, has dramatically increased [10]. At the end of 2012, UNHCR had responsibility for 35.8 million people, 10.5 million refugees and 17.7 million displaced persons ([4], p. 2). UNHCR estimates that the number of stateless persons is 10 million ([4], p. 2). The trend has been that mass human movements are increasingly caused by events that do not qualify as grounds for protection under the international regime of the Refugee Convention [11].

Moreover, despite states' obligations under the large body of law that governs refugees and stateless persons, they have been creative in avoiding the application of law or interpreting their legal obligations in the most restrictive possible ways to avoid generous grants of refugee recognition [12-16]. Under the substantial treaty law that the majority of states has now accepted are several fundamental guarantees towards refugees. The first is the guaranteed right of access to refugee status determination ("RSD") that grounds the Refugee Convention as well as other widely-ratified treaty and customary obligations towards refugees $[17,18]$. Although today there is no treaty or customary obligation on states to grant asylum, the right of access to refugee status determination is an underlying premise of the Refugee Convention. It is, as well, a necessary corollary of the jus cogens obligation of non-refoulement grounded both in treaty and international custom [6,19-21]. In spite of this fundamental obligation to allow access to procedures to determine refugee status, even people who might legitimately be Convention refugees face enormous barriers in accessing the right to RSD and the greater protection of asylum. In 2011, more than 1,500 migrants or refugees drowned or went 
missing while attempting to cross the Mediterranean Sea due to interdictions in territorial waters or diversions by states determined to prevent refugees from landing on their shores [22]. Once refugees get to Europe or North America, they may be unable to apply for asylum because of barriers to access. Measures instituted in the United States ("U.S."), Europe, and elsewhere, such as strict filing deadlines, safe third country provisions, return-back policies, lengthy immigration detention practices and other policies, present serious barriers to temporary or permanent refuge [23-27]. In the U.S., for example, immigration detention, including detention of asylum-seekers, has dramatically increased. The U.S. agency in charge of detention and removal, Immigration and Customs Enforcement ("ICE"), currently operates the largest detention and supervised release program in the country [28]. In fiscal year ("FY") 2010, a total of 15,769 asylum seekers were detained by ICE, and more than 3,192 asylum seekers were removed by ICE and the Department of Homeland Security [29]. In that year, an estimated \$150 million was spent on detaining asylum seekers [29,30]. These are undisguised measures to deter access to refugee or asylum applications - motives prohibited by the object and purpose of the Refugee Convention.

A second obligation that states accept in becoming parties to the Refugee and Stateless conventions is that of burden-sharing, which is based on the premise that refugees and stateless persons are the obligation of the world community, not just a burden for one or a few frontline states to absorb [31,32]. The possibility of durable solutions for refugees exists only through burden-sharing-placing on all states the shared obligations of host country absorption, third country resettlement and, at some point, safe and voluntary return to place of origin [32]. This obligation, as well, has been drastically undermined by resettlement states. Currently, resettlement benefits an extremely small number of refugees: in 2012 , only $0.84 \%$ of the world's refugees directly benefited from resettlement $(88,600$ resettled out of a total of 10.5 million refugees) ([4], pp. 2-3). In 2012, UNHCR submitted over 74,800 refugees for resettlement, 18\% less than in 2011 ([4], p. 18). Very few countries offer resettlement to refugees at all [33]. Twenty-two countries reported the admission of 88,600 resettled refugees during 2012 ([4], p. 19). The U.S. accepted the highest number (66,300) ([4], p. 19), but that is a tiny fraction of those eligible for and awaiting resettlement. Eleven percent of all resettlement submissions were for women and girls at risk, the highest percentage for this population in recent years ([4], p. 18).

The overwhelming majority of refugees and displaced persons are housed in countries least able to provide protection and assistance to them, and refugee populations are "warehoused," often for decades, in the developing world [34]. Developing countries host 8.5 million refugees, or $81 \%$ of the global refugee population ([4], p. 13). The 49 least developed countries provide asylum to 2.5 million refugees (24\% of the world total) ([4], p. 13). More than 1/3 of all refugees (34\%) reside in the Asia and Pacific region, with $70 \%$ of them (2.5 million) being Afghans ([4], p. 11). Sub-Saharan Africa is host to $1 / 4$ of all refugees, primarily from Somalia, Sudan, and the Democratic Republic of Congo ("DRC") ([4], p. 11). The Middle East and North Africa region hosts $15 \%$ of the world's refugees, mainly from Iraq and Syria, while Europe's share for the period is $17 \%$ ([4], p. 11; [35]). The Americas region has the smallest share of refugees (8\%) ([4], p. 11). Some 6.4 million refugees living in 25 different countries were in a protracted situation at the end of 2012 ([4], p. 12; [36]). They account for 30 protracted refugee situations in the world today ([4], p. 12). Based on these statistics, it is evident that the vast majority of refugees and persons of concern worldwide remain for long periods of time in regions of the world least able to house and support them. The 25 states hosting the largest 
number of refugees per capita are all developing countries, 16 of which are on the Least Developed Countries list ([4], p. 15). Further, countries with per capita incomes of less than $\$ 5,000$ host $50 \%$ of all refugees ([4], p. 15).

Burden-shifting as deliberate policy can be measured through resource allocation towards refugees. Many states are funneling ever-greater resources into mechanisms that undermine, rather than provide, protection to deserving refugees. According to UNHCR, total costs of administering asylum procedures and providing social welfare benefits to refugee claimants in 13 of the major industrialized states rose from around $\$ 500$ million in 1983, to around $\$ 7$ billion in 1990 [37]. The latter figure is over 12 times the global UNHCR budget for that year [37]. Developed countries currently spend at least $\$ 10$ billion to process refugee claims, compared to UNHCR's yearly global budget of approximately $\$ 3.6$ billion [38,39]. Updated comparative figures are extremely difficult to obtain, but it is reasonable to assume a gradual upward trajectory on both ends in keeping with the rise in numbers and the increasing disparity between the refugee burden in least developed countries and in the developed world. Even UNHCR's own internal budget priorities reflect discriminatory allocations. In 1993, for example, UNHCR allocated more funds to refugee protection in Europe alone than it did for the protection of three times as many refugees in Africa, Asia and the Middle East combined [40]. By 1995, UNHCR had spent less to assist the nearly 1.7 million Rwandan refugees in Burundi, Tanzania and Zaire than on its residual material assistance and other programs inside the former Yugoslavia [41]. Wealthy Western states reflect funding priorities that disproportionately allocate for deterrence, detention and removal, rather than for open access to refugee procedures, grants and settlement/assistance needs for refugees. In 2011, ICE budgeted \$2.02 billion for custody operations; \$276.6 million for transportation and removal (deportation) programs; and-combined with other smaller programs - a total of $\$ 2.9$ billion for detention and removal operations that include asylum-seekers as well as others in immigration custody [42]. In FY2014, the government of Australia has budgeted nearly $\$ 3$ billion for detention-related services and management of asylum-seekers arriving by boat [43]. In Canada in FY2011, 47\% of all detained immigrants were refugees [44]. The estimated cost to detain each refugee was $\$ 150-\$ 200$ per day [44].

The severe gaps and policy deficits that continue to weaken the protection regime for refugees and stateless persons might be mitigated by the promise of the UN's MDGs, especially for refugee and stateless women and girls. However, the MDGs address responsibility of states towards their citizens and residents, and say nothing of states' obligations towards persons without permanent legal status residing in their territory. Although UN agencies, including the UNHCR, have stated that they have responsibility to fulfill the MDGs, without explicit acknowledgement of state responsibility for the MDGs towards all persons on state territory, UN agencies cannot fulfill them on their own [45]. This omission has serious consequences for refugees and stateless persons, as well as for other forcibly displaced persons who cannot obtain state protection or status recognition. But the most severe consequences are felt by refugee, stateless, and other forcibly displaced women and girls.

\section{Implications of the MDGs for Displaced/Refugee Women and Girls}

UNHCR's most recent statistics reflect that women and girls represent $49 \%$ of persons of concern to UNHCR ([4], p. 34). They account for $48 \%$ of refugees ([4], p. 34). Overall, $4 \%$ of refugees are 
children below 18 years of age, and 13\% of all persons of concern are under the age of five ([4], p. 34). Although the world's refugees and forcibly displaced are relatively evenly divided between males and females, women and girls suffer disproportionately from certain kinds of violence, and from particular barriers that make it more difficult for them to obtain protection, legal status and the durable solutions of host country absorption or resettlement. Women and girls remain refugees or displaced for longer periods of time without status, and are more vulnerable to violence at every stage of displacement than men.

Refugee policies, trends, and statistics reflect that at every stage of the phenomenon of displacement, women and girls bear the brunt of violence, discrimination, harm and abuse [46]. Female refugees and displaced women are at daily risk of safety and sexual, physical and mental health, as they attempt to survive in refugee camps and manipulate treacherous journeys to safety. Yet they face even greater challenges trying to overcome the severe barriers erected by hostile resettlement states that expend disproportionately greater resources confining the burden of their care and protection to frontline states, rather than hosting or resettling them in safer countries. For the fulfillment of the MDGs, the critical aspect of forced displacement on women is their disproportionate vulnerability to lack of status, which results in states of refuge disclaiming responsibility for their legal protection. Hence, the MDGs that most matter to displaced and refugee women, specifically 1, 3 and 8, do not apply to them, as they are not "legally" the responsibility of the host states ([45], p. 3; [47-49]).

Because so many refugee women are either fleeing conflict that has already left them bereft of their male family members, or are fleeing persecution at the hands of male family members, they arrive in camps or elsewhere unaccompanied by spouses, brothers, or fathers. Women fleeing male-dominated societies are often disadvantaged in the simple process of self-identification. Unaccompanied women and girls from such societies may not have or have access to identity, paternity, marriage, or other documents usually held by the male head of household [50]. Male patriarchs may deliberately withhold these documents. It is close to impossible to complete the RSD process without identity and status documents, which is just the first stage for a refugee to access asylum [51,52]. Without basic documents, women and girls are particularly likely to be detained and viewed as economic migrants, perhaps as part of trafficking rings, or as suspicious irregular migrants ([52], p. 13). In much of the developed world, there is still inadequate access to counsel, representatives, or guardians to advocate for unaccompanied women or separated children through a complex refugee/asylum process that is almost impossible to navigate without competent representation $[53,54]$. Some of these difficulties that have an especially harsh impact on women are discussed below.

Forced displacement remains primarily a response to violence, whether from armed conflict (international or civil), domestic abuse, or organized violence, and it is women and girls that are particularly affected by both armed conflict and other forms of violence. Of course, armed conflict inevitably deprives households of their males and increases the prevalence of women and child-headed households. Women also face extreme forms of violence in the home and society that causes them to flee. The UN has documented the type and scope of sexual and gender-based violence around the world for some time, which include rape, forced impregnation, forced abortion, trafficking, sexual slavery, forced marriage, female genital mutilation ("FGM") and, more recently, the intentional spread of sexually transmitted infections [55,56]. For women seeking refugee status, these may be characterized as gender-based grounds of persecution or gender-based forms of persecution [57]. The primary targets of this gender-based violence are women and girls, causing them to flee their homes or 
subjecting them to forcible removal from their homes and countries of origin. Gender-based violence and armed conflict also go hand-in-hand. Rape, for example, has also served a "strategic purpose" as an instrument of ethnic cleansing in conflicts such as the Bosnian War [58]. It is estimated that between 20,000-50,000 women were raped in Bosnia and Herzegovina in the 1990s [59]. Rape has also been a prominent feature of the Sudanese government's ethnic cleansing campaign in Darfur [60]. Women and girls are still at risk once they reach refugee camps. For example, in the Sudanese refugee camps in Chad, collecting firewood and fetching water are chores traditionally allocated to women. These chores separate the women and girls, leaving them vulnerable to attack [60]. Female and child heads of household are extremely vulnerable to severe violations of rights, marginalization in their communities, and lack of legal status when they flee ([51], p. 20; [61]).

However, for women and girls, entering and finding protection in another country has become increasingly difficult. Women may have the primary responsibility for the care of children and may lack adequate financial resources to travel to seek safe haven [62]. Without regular means of reaching a country where they can seek asylum, refugees resort to smugglers and dangerous routes to reach safety. The high cost of smugglers may be beyond many women's reach ([62], p. 6). Women and adolescent girls are often forced to offer sex to border guards to obtain permission to pass, and are at greater risk of being trafficked into prostitution and forced labor [63-66]. Western border protectionism has resulted in a surge of refugee smuggling and trafficking, both for humanitarian reasons, such as the Afghan refugee smuggling networks out of Pakistan and Iran, and for exploitation, such as the trafficking of Iraqi refugee girls and women through Jordan and Syria [67]. In Jordanian refugee camps, hundreds of women and girls have been sold under the guise of "temporary marriage" [68]. States' actions on the domestic, global and regional levels have a domino effect on refugee flows with a disproportionate impact on women: $80 \%$ of all people trafficked are women and girls [69]. Too often, unaccompanied or separated girls become trafficking victims and disappear during the course of the asylum process. UNHCR estimated that between 2003 and 2008, 4,000 Iraqi women refugees disappeared, including one in five under the age of 18, most of whom were likely trafficked [70]. According to the Organization for Security and Cooperation in Europe, over 1.2 million children worldwide are trafficked annually for sexual exploitation, domestic slavery, or child labor [71].

As states are all too eager to claim, it is easy to confuse asylum seekers and refugees with economic migrants. More and more frequently, governments seeking to control illegal migration impose visa restrictions or intercept individuals who do not have proper documents. New legislation with expanded detention and new anti-terrorist policies, put in place since the World Trade Center attacks of 11 September 2001, has made reception countries extremely hostile to refugees and other forcibly displaced persons [72]. Such restrictive measures affect everyone trying to seek asylum or safe haven, but additional barriers exist for women and girls at each stage of the journey towards seeking safety, whether temporary protection or permanent asylum. UNHCR, like other UN agencies, has taken up the challenge of the MDGs, indicating that it shares the responsibility for achieving them. As UNHCR stated in its Population, Refugees and the Millennium Development Goals: A UNHCR Perspective, none of the eight MDGS deals specifically with refugees. The Report cites the High Commissioner: "Displaced populations should be included in the MDG projects as a way to strengthen protection and durable solutions for them...UNHCR will participate in the pursuit of the Millennium Development Goals, such as combating HIV/AIDS, achieving universal primary education, and promoting gender 
equality/empowerment of women, by ensuring the application of agreed standards and indicators as well as in the preparation of guidelines" [45]. However, UNHCR recognizes the shortcomings of its own commitment in the absence of specific inclusion of displaced persons and refugees in the responsibility of states for the MDGs. UNHCR relies on funding from donor states, and this funding depends on international priorities, established through perceived state legal obligation and self-interest. Vulnerable populations such as the displaced who lack status in the host territories are on the lowest rung of the priority ladder, as the statistics and policies here demonstrate. The global partnership envisioned by MDG 8 has not been realized, as developed countries have not shared in the burden of refugee assistance, and the fulfillment of the MDGs reflects the same pattern: in the developed world, MDG targets are fairly consistently met, while in the developing world, MDG targets fall short. However, across the globe refugees and displaced populations are significantly and materially left outside MDG targets by states, and within those, women and girls are at greatest risk in key categories ([37,38]; [47], p. 15). Some of the main perils for women, and how both legal protections for refugees/displaced persons and the MDGs are failing them, are summarized below.

\subsection{Refugee Women Seeking Local Integration in Host Countries}

Displaced women and girls remain in refugee camps for lengthy periods of time ([50], pp. 9-10). The majority of refugee camps are located in unsafe areas, often at borders where conflict is taking place. Women are at particular risk during both cross-border conflicts and prolonged periods in camps. The longer camps remain in operation, the fewer resources they attract, and the more difficult the circumstances for the women refugees remaining there. Poor camp conditions severely constrain individual privacy, livelihood opportunities, fundamental rights and participation in decision-making processes - all of which lead to protection risks for women and girls ([50], pp. 9-10; [73]). For example, a recently released study by the American Journal of Public Health shows staggering levels of rape and sexual violence in the DRC, estimating that more than 400,000 women suffered rape or sexual violence in 2007 alone [74]. As has been publicized in the Darfur refugee camps, women and girls suffer sexual and other violence just trying to survive each day [75]. For instance, women and girls may be attacked as they look for firewood and water outside the camp ([50], p. 203). As economic resources are depleted, girls are married off at younger and younger ages ([50], p. 10). Survival sex becomes the only way to support themselves and their families ([50], p. 10).

Displaced women and girls living in host countries in non-camp rural areas may face significant threats as well. Without recognized legal status, women and girls resort to an underground economy where they are vulnerable to exploitation. Their work as low-wage laborers force them to live in squalid conditions. They may have very limited ability to move freely and face regular police or military roadblocks, further exposing them to harassment or violence. They may have to obtain permission to travel or be accompanied by a male relative if they need medical or other assistance. Access to documentation or to medical or other humanitarian assistance may present great difficulties, including travel for long distances at considerable cost and risk ([50], pp. 6-11; [76-78]).

Forcibly displaced women and girls in urban areas often live in sub-standard conditions and lack access to fundamental services, such as education and health care where many schools lack adequate sanitation facilities - a further disincentive to girls attending schools [79]. Malnutrition is also 
prevalent in these countries and has a direct effect on cognitive development [80]. Often without adequate financial resources to afford rent, women risk sexual exploitation by landlords ([50], p. 9). Women and girls employed as domestic workers may face violence and exploitation at the hands of their employers [81,82].

In host countries, women refugees must adapt to new cultural environments in order to successfully integrate. Those without male relatives must both be caregivers and assume traditionally male roles in order to bring resources into the household [83]. These dual roles make it more difficult to learn a new language and adapt to a new environment, causing further isolation and marginalization $[84,85]$. The added pressures make dealing with pre-existing trauma and other problems more difficult. All of these are exacerbated by drawn-out asylum procedures and the uncertainty of a durable solution in the foreseeable future ([50], pp. 67-68).

\subsection{Refugee Women Seeking Resettlement and Access to Fair Asylum Procedures}

The harms described above highlight the serious problems women refugees face, mostly in the developing world. It is too easy to assume that these hardships are just the additional hazards of the poverty that result from becoming a refugee in the first place. Women also face particular disadvantages and systemic harm in the developed world where they seek asylum and permanent status. For those fortunate enough to have access to resettlement, the resettlement process and the asylum process within third states - quite aside from the refugee determination issues-are also fraught with particular problems for women and girls. Divorce, child custody disputes, polygamous marriages and unaccompanied minors or separated families all present far greater problems for women seeking resettlement or asylum status than for men [46]. In a new country, unemployment, underemployment, trauma, and other serious adjustment issues may result in domestic violence, which once again primarily affects women.

\subsubsection{Procedural Challenges}

As distasteful as stereotypes are, particularly in the highly-charged subject of immigrants and refugees, unfortunately, some stereotypes about women refugees find support in empirical evidence. Women refugees - and not only those from the developing world - are likely to have less education and language capabilities than men [86]. This particular phenomenon has many deleterious consequences for women refugees in making asylum claims. They often do not become aware that they have rights and options in time to pursue them, particularly in the face of policies like the one-year filing deadline imposed on asylum-seekers in the U.S. Whether accompanied or not, women may lack experience and confidence in dealing with authority figures, and hence appear "not credible" to adjudicators - the kiss of death for an asylum claim [87-90]. Other cultural factors play heavily in many women's ability to articulate their claims, particularly to male adjudicators. Without access to female services and adjudicators, a woman may be culturally unable to move forward on her claim; she may be extremely reluctant to discuss details of her persecution with strangers, let alone to male authoritative figures, particularly if that information is shameful, embarrassing, or could put her in grave danger if revealed to her family ([46], pp. 78-80; [91]). A woman may not want her husband or other family member to know about her persecution. Many women remain silent about experiences 
directly related to their claims for fear of their family's reactions [92]. Faced with these cumulative challenges, many refugee women do not feel confident in the asylum process and avoid or do not fully participate in preparing their claims - thereby defeating their claims altogether.

Women refugees often have no choice in deciding who will be the main applicant in their asylum claim. States and refugee agencies frequently consider only the claim of the head of household as the "principal applicant" [93]. This is standard operating procedure for UNHCR RSD, even where female family members have experienced severe persecution. Agencies advocating for refugees also focus on the male head of household [94]. As previously noted, women, far more frequently than men, do not have access to requisite documents, including personal documents. These factors make it difficult for women to access individual procedures. Even if male family members accompany them, women may be discouraged from making a claim when husbands or other family members have already filed one. This is disastrous when the woman either has the strongest claim on the merits or may have a claim quite independent of her male spouse or relative [95].

\subsubsection{Legal Challenges}

Domestic laws on asylum and refugee status recognition incorporate particular barriers and systemic discrimination in adjudicating women's claims. Most asylum claims are granted on the basis of persecution on the basis of political opinion, and most political opinion claims are made by men. Women's claims are most commonly based on violence in the home or community, and most of these are not viewed as based on actual or imputed political opinion. Adjudicators frequently fail or refuse to recognize gender-related forms of persecution as falling within refugee definition. For example, until very recently, the administrative appellate body for immigration and asylum claims and the U.S. courts of appeals consistently failed to recognize rape as persecution [96-103]. The same is true of FGM, which many courts still view as either a traditional cultural practice or, if the woman has already been mutilated, an indication that she no longer has a fear of future persecution [104-107]. Many claims of violence in the home or community are viewed as "private" violence, and neither political nor the responsibility of the state. Courts may not view persecution carried out by private individuals, but tolerated by the state, as falling within the refugee definition [108]. Such adjudicator perspectives have made it exceedingly difficult to succeed in characterizing severe abuse by a family member, gang violence, or organized crime that targets women and girls, as persecution [109-111].

Notwithstanding the efforts of UNHCR and the framework espoused in many state guidelines on refugee women claims, most states do not recognize gender as a particular social group [91,108,112-114]. In 1991, UNHCR issued guidelines encouraging all member states to adopt an interpretation of the 1951 Convention under which women who faced inhumane treatment because of their failure to conform to the social mores of their country should be considered as a particular social group and advocating improvements in the standards of asylum and refugee determination procedures to improve the access of women to refugee status [115].

Canada was the first country to integrate gender guidelines into their national asylum policies. In 1993, Canada issued guidelines which included a category specifically outlining how a woman refugee claimants may be part of a gender-defined social group [91]. In 1995, the US Immigration and Naturalization Service issued a memorandum that directed immigration officers to consider that 
women may face specific types of persecution and noted that some US jurisdictions have concluded that gender can define a particular social group [116]. In Europe, only two countries have adopted any kind of gender directives or guidelines into their asylum procedures-Sweden and the United Kingdom ([62], p. 181). The Swedish guidelines specifically reject the possibility of considering gender as a defining characteristic of a particular social group ([62], p. 181).

The few states that have adopted guidelines fall short of actual implementation of the key aspects of the UNHCR guidelines ([62], p. 181). Even those states that have adopted guidelines fail to consistently implement them when processing asylum claims ([62], p. 181). Thus, even though the majority of women refugee claims are litigated under the particular social group ground, they are rarely successful on that ground [117-120].

Political opinion is the most frequent ground of successful claims in general, but it is least frequently applied to women [121-129]. Because women's claims most often relate to abuse in the home or within the family, the abuse is seen as a private, not public matter, and certainly not as a form political expression [130]. Yet, women and girls opposing harmful practices and violence that violate their fundamental human rights should be seen as facing persecution on account of political opinion [131-133]. Religious-based grounds are probably the most complex claims for women, as both litigators and adjudicators routinely fail to accurately analyze such claims when the woman is the same religion as the society of origin. These claims, focused on opposition to cultural and religious norms, fare poorly in Western courts [133-142].

Other restrictive interpretations of the refugee definition may prove insurmountable. For example, the U.S. has interpreted the innocuous requirement in the Refugee Convention phrase "because of" to require that the persecution or threat to life or freedom to be very tightly linked to one or more of the five grounds enumerated in the 1951 Refugee Act: race, religion, nationality, membership in a particular social group, or political opinion. This interpretation imposes a separate and often impossible barrier to most women's claims. In the seminal case of INS v. Elias-Zacarias [143] the Supreme Court interpreted the Convention's "because of" phrase as "on account of," transforming this language, known as the nexus relationship, to require the applicant to prove with a high degree of certainty the connection between the persecutor's intent and one or more of the enumerated grounds [144-151]. Under the Supreme Court's interpretation of the relationship between the persecutor's motive and the victim's protected characteristic, a female rape victim could reasonably be expected to prove that the government agents who raped her did so primarily because she was a family member of a political opponent. As a matter of practical proof, few women could provide such evidence, let alone in the circumstances of rapid flight to safety. Such decisions have followed from the Supreme Court's Elias-Zacarias decision - a clear illustration of how removed even the most sophisticated adjudicators are from the realities of women refugees [152-154].

All these barriers have turned the promise of the treaty regimes of the Refugee Convention, the Convention on Stateless Persons, and whatever weak protections exist for other displaced persons into a hollow one for the majority of the forcibly displaced, and particularly for displaced women and girls. The weaknesses in these regimes reflect a metamorphosis from a refugee burden-sharing agreement into a burden-shifting one, contributing to the phenomenon of developing countries bearing the brunt of refugee flows. Refugee and other forcibly displaced women are forced to remain in the poorest areas for protracted periods, where they have the least access to rights and safety. If they are among the 
fortunate to get to the developed world seeking asylum, they face additional restrictions. Barriers such as the failure to recognize rape as persecution, the requirement that women prove the motives of their persecutors, the constraints of a one-year filing deadline or the demand for documentation that is unobtainable, all have huge consequences for refugee protection, particularly for women and girls. Women and girls at each stage of displacement continue to be victimized and remain the most vulnerable of the displaced.

\section{Conclusions and Proposal to Expand the MDGs to Include State Responsibility towards Refugees and the Forcibly Displaced, Particularly Women and Girls}

The realities of the barriers and unique risks faced by women in the various stages of displacement create an opportunity for the MDGs to fill some of these critical gaps. MDG 1, reducing global poverty, includes a number of targets. Target $1 \mathrm{~A}$ aims at halving the proportion of people living on less than $\$ 1.25$ per day by 2015 . According to the UN, this target was met five years ahead of the deadline. However, a projected one billion people will still be living on less than $\$ 1.25$ a day by next year [155]. A large proportion of these will be the displaced, and displaced women will be a majority of these because of their long stays in refugee camps and other displaced communities where they are dependent on donor generosity rather than their own earning power or benefits as of legal right. Target 1.B aims to achieve full and productive employment and decent work for all. The UN indicates for this target that although there is a $67 \%$ reduction in insecure or poorly paid jobs from 1001-2011, they still account for $58 \%$ of all employment in the developing world and women and youth are "more likely to hold such positions" [155]. Displaced and refugee women represent a large proportion of this unemployed and insecurely employed population, as they remain in urban spaces and isolated communities without legal status in their host states for long periods of time. Target 1.C aims to halve the proportion of people who suffer from hunger between 1990-2015. In its most recent assessment, the UN's figures include that " 850 million people, or nearly 15 percent of the global population, are estimated to be undernourished" [155]. The UN links the populations suffering extreme hunger with the "more than 42 million people [who] have been uprooted by conflict or persecution" [155]. If state responsibility specifically includes the displaced residing on their territory, joint UN-state obligations can help lift this vulnerable population out of poverty to meet this target.

MDG 3, which aims to promote gender equality and empower women, cannot be met without basic necessities. Target 3.A of MDG 3 focuses on the elimination of gender disparity in education. Girls' dropout rates have increased exponentially in developing countries. Trafficked women and girls are excluded from educational opportunities, as are women in refugee camps with educational facilities funded according to vacillating priorities of international humanitarian assistance rather than legal obligation. Overall, sixty-eight countries have yet to achieve gender parity in their primary education systems ([80], p. 6). The UN's progress report includes the following:

Gender inequality persists and women continue to face discrimination in access to education, work and economic assets, and participation in government...

Violence against women continues to undermine efforts to reach all goals...

Poverty is a major barrier to secondary education, especially among older girls...

Women are largely relegated to more vulnerable forms of employment [156]... 
In May 2013, the World Bank released hopeful statistics, reporting that 20 countries of concern had met one or more of the MDGs and six countries were on track to meet targets before 2015 [157]. For example, eight fragile countries, including Guinea, Nepal and Bosnia, have halved extreme poverty, meeting Target 1.C of MDG 1. Equalizing women's access to education, a target of MDG 3, has seen success in many conflict-affected countries, including the Republic of Congo and Yemen. To improve girls' access to education, strategies like mobilizing communities, making financial support for girls a priority, increasing school safety and utilizing gender-sensitive teaching methods have proven successful ([80], p. 10).

Despite such progress, fully realizing these MDGs is very difficult for displaced populations. With 2015 fast approaching, and only 20 percent of conflict-affected countries meeting the poverty goal, the majority of states will fall short of the targets. World Bank officials fear that progress may also be reversed as countries relapse into conflict. Furthermore, the true plight of refugee women has yet to be fully realized because MDG data fails to disaggregate between the sexes. If there is to be any hope of meeting the MDGs, progress indicators must be altered [158]. MDG 1 measurements should consider access to employment, financial services and social security. MDG 3 data should reflect gender-based violence and the prevalence of discriminatory attitudes in local institutions. Finally, MDG 8 should measure the effects that aid to rural programs has on empowering women and equalizing participation in rural infrastructure. A huge part of the world's female population-refugee and displaced women and girls - remain vulnerable and outside the protection of state responsibility because states lack the commitment to implement international legal norms for refugees and other displaced persons in the manner intended by the drafters of the Refugee and Stateless Conventions. The MDGs can help to address these gaps if states are made directly responsible for reaching MDG targets for this population.

UNHCR has begun measuring MDG targets against refugee and displaced persons' situations. In one study completed in 2006, Bart de Bruijn conducted comparative research on living conditions of refugees and displaced persons in Armenia, Ecuador, Sri Lanka and Pakistan [47]. The report found that the refugees and displaced persons in developing countries were overall significantly worse off as measured by key MDG targets than those in more developed countries, as the indicators for MDG 1, 3 and 8 show in a comparison of these populations in Sri Lanka, Armenia, Ecuador and Pakistan. But stage of development alone did not account for the serious MDG gaps for refugees and displaced populations. For example, the study reflected "serious food security problems" for all the displaced populations, regardless of UN agency resource allocations. Already vulnerable populations due to cultural factors face greater vulnerabilities when they are displaced, as measured by the MDGs. This study, for example, compared the high primary school attendance for child refugees in Sri Lanka (primary school enrollment $=96 \%$; drop-out rate $=8 \%$; and youth literacy $=97 \%$ ) to Afghan refugees in Pakistan, with dismal rates of attendance and literacy (11\% enrollment in primary school; $59 \%$ dropout rate from primary school; 57\% illiterate youths) ([47], p. 37). Women and girls are even worse off by most of the measures in the categories assessed by the study. For example, refugee women are significantly lower in key targets for MDG 3 in each one of the countries studied. In Pakistan and Sri Lanka, displaced and refugee women represent $8 \%$ and $18 \%$ in non-agriculture employment ([47], p. 38). The study concludes that this reflects "poor female integration in the monetary economy" ([47], p. 38).

MDG 8 is perhaps the most significant for all refugees and displaced persons, and is echoed in the burden-sharing obligation that underpins the Refugee Convention, the Stateless Persons Convention, 
and indeed under most of the international human rights treaties. However, in the six targets to be met under MDG 8, none address the particular concerns of refugees and displaced persons. The Millennium Declaration states that "in addition to our separate responsibilities to our individual societies, we have a collective responsibility to uphold the principles of human dignity, equality and equity at the global level" [2]. For displaced women and refugees, these principles are particularly important in ensuring that MDG 8 has particular application for them.

A UNHCR report underscores that its "ability to assess each of the MDGs or targets in light of the ICPD [International Conference on Population and Development] Programme of Action is hampered by the fact that refugees are not explicitly addressed in the MDGs" ([45], p. 4). UNHCR emphasizes the heart of the problem: "In addition to their socio-economic well-being, it is important to note that protecting refugees and finding durable solutions is a key responsibility of Governments and the international community" ([45], p. 4). A critical step on that path is to explicitly require states to take on the responsibility for meeting the UNs MDGs with regard to all persons on their territories, and all persons for whom states have a shared responsibility, with particular emphasis on refugee and displaced women and girls.

As this article went to press, the UN's Post-2015 Development Agenda documents were published [159,160]. The Post-2015 development goals reflect an increased awareness of the gaps in the MDGs, including those affecting migration flows. However, a critical conversation has not yet occurred in the global consultations on post-2015 MDGs to address serious discrepancies between national policies that discriminate between those "legally present" and those considered illegally present, whether forced migrants or putative refugees not meeting national standards for refugee recognition. Nor do the gaps address how the MDGs are affected by the discrepancies between permissible discrimination under international treaties based on citizenship/residence status and prohibited discrimination on the basis of race, color, sex, political opinion, and national or social origin. Discrimination based on citizenship/lawful residence is widely accepted as an attribute of state sovereignty, and the tension this creates has not been adequately explored as a major problem for realizing the MDGs. For example, among the documents issued for the 2015 goals are A Renewed Global Partnership for Development and the Population Dynamics in the Post-2015 Development Agenda [160,161].

The Renewed Partnership identifies gaps that include the lack of a "strong normative foundation" for the MDG 8 framework, in that it "failed to integrate international human rights commitments, including the duty of international cooperation for development..." ([160], p. 5). The document focuses exclusively on economic development goals from the perspective of the obligations of developed states towards the developing world in implementation of shared responsibilities. It makes no mention at all of the shared responsibility towards refugees and forced migrants, or how the development obligations of developed states will extend towards persons who are not legally present in the territories in which they reside. Who is responsible for ensuring the MDGs are met for persons not considered citizens or residents of state territories when development aid is distributed? Global responsibility towards refugees and forced migrants is a critical gap in MDG 8 that the post-2015 Agenda fails to mention.

There is small progress in the results of the consultations on Population Dynamics. The first Principle listed in the Population Dynamics, under "Rights-based and gender-responsive policies" is: "Adopt human rights-based and gender-responsive approaches to addressing population dynamics, 
including sexual and reproductive health and rights, promoting dignity and gender equality through laws, policies and practices that eliminate stigma, discrimination, coercion and violence" ([161], p. 47). Under the thematic priorities for "High fertility and population growth," the document lists: "Eliminate all forms of gender-based violence against women and girls, including harmful practices, through prevention efforts engaging young people and men, and ensuring access to health, social and legal services for all victims" and "Eliminate early and forced marriage" ([161], p. 49). Under priorities for "Migration and human mobility," the document calls on states to: "Eliminate policies that create barriers for migrants to access their human rights such as laws that criminalize migrants in an irregular situation and to explore alternatives..." ([161], p. 50).

These principles touch on the core gaps mentioned above, but give no insight as to how the gaps are to be addressed, or how the discrepancies between perceived legal obligations towards persons lawfully present on territory and those without status are to be resolved in order to meet the goals. How are policies that prevent migrants from accessing human rights to be eliminated when discrimination based on citizenship status is widely institutionalized and perceived as "legal"? The most forward-looking document on these questions is the Concept Paper that emerged from the Expert Policy Dialogue on Migration on the Post-2015 Development Agenda [162]. The paper notes that MDG 8 does not mention migration, despite its huge impact on achieving that goal. It states that, "The power of migration as an enabler of development argues for the inclusion of migration indicators in the elaboration of many if not most of the goals of the post-2015 development agenda" ([162], p. 4). It also lists among positive migration indicators that could be tracked to determine the success of MDG 8: "The proportion of international migrants lacking legal authorization to reside in their countries of residence declines ... States take steps to eliminate discrimination (on grounds of race, religion, ethnicity, national origin, etc.) among migrants who are legally present in their territories" ([162], p. 5). None of this, however, goes far enough. It focuses on the added value of migration remittances to available development aid, but does not go to the heart of the gaps in the populations who will benefit, and what is to be done about those who are not legally present in host territories, and towards whom the host countries are legally entitled to leave out of their obligations under the MDGs. The Concept Paper itself recognizes this core problem:

The international community has not yet found a way to resolve the dilemmas that people have the right to leave any country including their own ... but they do not have the right to enter another country that is not their own .... [R] estrictions on the entry and stay of non-citizens remain a fundamental prerogative of sovereign states and a universal practice ([162], p. 5).

The Concept Paper itself acknowledges that these issues are not likely to be seriously addressed in the near future [163], but suggests a comprehensive new Development Goal that would go a long way towards addressing some of the most serious gaps: "Creating cooperative agreements for human mobility to ensure safe, lawful, less costly movements across or within borders, producing positive development outcomes for all stakeholders" ([162], p. 5). This author suggests that the United Nations MDG process needs to urgently discuss incorporating this as MDG 9, and begin a new round of global consultations to frame the key indicators that will close the huge gap in the reach of the MDGs that leaves vulnerable refugee and forced migrant women and girls out in the cold. 


\section{Acknowledgments}

Remarks based on this paper were presented at the International Conference on Protection of Women's Rights sponsored by the Italian Cultural Institute, New York, on 24 September 2010.

The author thanks Boston University School of Law students Danessa Watkins and Eileen Morrison, whose invaluable research assistance made completion of this paper possible.

\section{Conflicts of Interest}

The author declares no conflicts of interest.

\section{References and Notes}

1. Department of Public Information, United Nations. "United Nations Millennium Development Goals.” Available online: http://www.un.org/millenniumgoals/ (accessed on 23 July 2012).

2. UN General Assembly. "United Nations Millennium Declaration, Resolution adopted by the General Assembly." 18 September 2000, A/RES/55/2. Available online: http://www.refworld.org/docid/3b00f4ea3.html (accessed on 20 June 2013). The UN details the eight main development goals aimed to be completed by 2015.

3. UN General Assembly, 5th Session. "Statute of the Office of the United Nations High Commissioner for Refugees." 14 December 1950, A/RES/428(V), Annex 1. The resolution establishes the UNHCR for the purpose of "providing international protection, under the auspices of the United Nations, to refugees...."

4. United Nations High Commissioner for Refugees (“UNHCR”). Global Trends 2012. Geneva: UNHCR, 2013, 3. Available online: http://www.unhcr.org/51bacb0f9.html (accessed on 19 June 2013).

5. International Federation of Red Cross and Red Crescent Societies. World Disasters Report 2012: Focus on Forced Migration and Displacement. Edited by Roger Zetter. Lyons: Imprimerie Chirat, 2012, 117. Available online: http://www.ifrcmedia.org/assets/pages/wdr2012/ (accessed on 17 June 2013).

6. UN General Assembly. "Convention Relating to the Status of Refugees ('CRSR')." United Nations, Treaty Series 189, 28 July 1951, 137. Available online: http://www.refworld.org/docid/3be01b964.html (accessed on 10 August 2012) (CRSR defines who is a refugee, their rights and the legal obligations of states.).

7. UNHCR. "States Party to the Statelessness Conventions and Pledges to Accede." Available online: http://www.unhcr.org/4ff2e44a9.html (accessed on 28 August 2013).

8. UNHCR. "Convention on the reduction of statelessness." 30 August 1961, 4. Available online: http://www.unhcr.org/3bbb286d8.html (accessed on 21 June 2013).

9. UN General Assembly. "Question of the Establishment, in Accordance with the Convention on the Reduction of Statelessness, of a Body to Which Persons Claiming the Benefit of the Convention may Apply." 30 November 1976, A/RES/31/36, 3. Available online: http://www.unhcr.org/42bc04ac2.html (accessed on 21 June 2013). 
10. UNHCR. "Population Levels and Trends." In UNHCR Statistical Yearbook 2011. Geneva: UNHCR, 2012, 21. Available online: http://www.unhcr.org/516286589.html (accessed on 17 June 2013).

11. United Nations. "Resources for Speakers on Global Issues-Refugees." Available online: http://www.un.org/en/globalissues/briefingpapers/refugees/nextsteps.html (accessed on 20 June 2013). "The reasons for displacement today are far more complex than those envisaged under the 1951 Convention, and the distinctions between refugees and migrants and voluntary and involuntary movements are becoming increasingly blurred."

12. Among the most important instruments of refugee and displaced persons' protections are the following [12-16]: UNHCR. "Convention on the Reduction of Statelessness." 30 August 1961. Available online: http://www.unhcr.org/3bbb286d8.html (accessed on 23 July 2012).

13. UNHCR. "OAU Convention Governing the Specific Aspects of Refugee Problems in Africa." 10 September 1969. Available online: http://www.unhcr.org/45dc1a682.html (accessed on 23 July 2012).

14. UNHCR. "Cartagena Declaration on Refugees." 22 November 1984. Available online: http://www.unhcr.org/refworld/docid/3ae6b36ec.html (accessed on 23 July 2012).

15. UNHCR. "Protocol No. 4 to the Convention for the Protection of Human Rights and Fundamental Freedoms." 16 September 1963. Available online: http://www.unhcr.org/refworld/ docid/3ae6b3780.html (accessed on 23 July 2012).

16. UNHCR Centre on Housing Rights and Evictions. "The Pinheiro Principles: United Nations Principles on Housing and Property Restitution for Refugees and Displaced Persons." Geneva: Centre on Housing Rights and Evictions, n.d. Available online: http://www.unhcr.org.ua/img/uploads/docs/PinheiroPrinciples.pdf (accessed on 24 July 2012).

17. See Kate Jastram, and Marilyn Achiron. Refugee Protection: A Guide to International Refugee Law. Geneva: Inter-Parliamentary Union and UNHCR, 2001. Available online: http://www.unhcr.org/cgi-bin/texis/vtx/home/opendocPDFViewer.html?docid=3d4aba564 (accessed on 10 August 2012). The article provides a compilation of the rights and protections granted to refugees by the body of international law and treaty agreements and guiding future implementation of refugee law by parliamentarians.

18. UNHCR Division of International Protection Services. A Thematic Compilation of Executive Committee Conclusions, 6th ed., 2011, 25-28. Available online: http://www.unhcr.org/cgibin/texis/vtx/home/opendocPDFViewer.html?docid=3d4ab3ff2 (accessed on 10 August 2012). "Reaffirms that the institution of asylum, which derives directly from the right to seek and enjoy asylum set out in Article 14 (1) of the 1948 Universal Declaration of Human Rights, is among the most basic mechanisms for the international protection of refugees.... Emphasizes the primary importance of non-refoulement and asylum as cardinal principles of refugee protection and encourages States to intensify their efforts to protect the rights of refugees ... to ensure conditions of asylum compatible with recognized international standards..."

19. Guy Goodwin-Gill. “A Legal Analysis.” In Mixed Migration Expert Roundtables: 10-Point Plan Expert Roundtable No. 1: Controlling Borders While Ensuring Protection. Geneva: UNHCR, 2008, §5.3. Available online: http://www.unhcr.org/4a27bf566.html (accessed on 23 July 2012). 
20. Jean Allain. "The Jus Cogens Nature of Non-Refoulement." International Journal of Refugee Law 13 (2011): 535-42. "Norms of jus cogens ... are higher norms of which no violation is allowed. In no circumstance may a State legally transgress the norms of jus cogens, for they are considered norms so essential to the international system that their breach places the very existence of that system in question... Thus, there is a need to hold inter-governmental institutions to their obligations and, in the case of non-refoulement, to ensure that States, acting within such institutional frameworks, understand that they have agreed to its jus cogens nature."

21. UNHCR Division of International Protection Services. Conclusions Adopted by the Executive Committee on the International Protection of Refugees. 2009, vol. 33, No. 25(b). Available online: http://www.unhcr.org/refworld/pdfid/4b28bf1f2.pdf (accessed on 10 August 2012). "Reaffirmed the importance of the basic principles of international protection and in particular the principle of non-refoulement which was progressively acquiring the character of a peremptory rule of international law..."

22. UNHCR. "More than 1,500 drown or go missing trying to cross the Mediterranean in 2011." The UN Refugee Agency, 31 January 2012. Available online: http://www.unhcr.org/4f2803949.html (accessed on 16 June 2013).

23. Stephen H. Legomsky. Secondary Refugee Movements and the Return of Asylum Seekers to Third Countries: The Meaning of Effective Protection. Geneva: UNHCR Department of International Protection, 2003, vol. 6, 16. Available online: http://www.unhcr.org/cgibin/texis/vtx/home/opendocPDFViewer.html?docid=3e6cc63e4 (accessed on 10 August 2012). Legomsky explains safe third country provisions as "[t]ypically, asylum adjudicators are then instructed to refuse to decide an asylum claim in substance if the person earlier passed through, and should have sought asylum in, a third country that is on that 'safe' list..." and discussing the problems that arise including the danger of a chain of refoulement back to the country of origin in violation of the Refugee Convention.

24. Karen Musalo, and Marcelle Rice. "The implementation of the one-year bar to asylum." Hastings International and Comparative Law Review 31 (2008): 695-96. The article details the U.S.'s strict one-year filing deadline for asylum and showing a sharp increase in the number of late filers denied asylum despite the fact that the UNHCR "opposed the enactment of the one-year bar..."

25. Alexander J. Wood. “The 'Pacific Solution': Refugees Unwelcome in Australia." Human Rights Brief 9, no. 3 (2002): 22-25. ("In recent years Australia has instituted a series of laws and policies requiring the mandatory detention of certain refugees and asylum seekers and, in some instances, their forcible relocation to other countries. These measures place Australia in probable violation of its obligations under international law including, inter alia, the Convention Relating to the Status of Refugees... The [UNHCR], in Revised Guidelines on Applicable Criteria and Standards Relating to the Detention of Asylum Seekers, notes as a general principle that there should not be mandatory or excessively lengthy detention of asylum seekers."

26. "Human Rights Watch." European Union: Country Summary, January 2012. Available online: http://www.hrw.org/sites/default/files/related_material/eu_2012.pdf (accessed on 16 August 2012). Human Rights Watch addresses a variety of European Union policies that discriminate 
against refugees, including "broad grounds for detention, low standards on access to social assistance and healthcare, and expanded use of fast-track asylum procedures..."

27. Simon Troller. "With a Migrant Crisis Looming, the EU Should Learn from its Past Mistakes." Human Rights Watch, 6 April 2011. Available online: http://www.hrw.org/news/2011/04/06/ migrant-crisis-looming-eu-should-learn-its-past-mistakes (accessed on 16 August 2012). Troller describes the European Union's failure to protect asylum seekers through, for example, policies like the Dublin II regulation that places an unfair burden on external border states to assume responsibility for a disproportionate majority of migrants.

28. Dora Schriro. "Immigration Detention Overview and Recommendations." U.S. Dept. of Homeland Security, Immigration and Customs Enforcement, 6 October 2009, 2. Available online: http://www.ice.gov/doclib/about/offices/odpp/pdf/ice-detention-rpt.pdf (accessed on 10 August 2012).

29. Department of Homeland Security, U.S. Immigration and Customs Enforcement. "Detained Asylum Seekers: Fiscal Year 2009 and 2010 Report to Congress." 20 August 2012, 4, 8. Available online: http:/www.ice.gov/doclib/foia/reports/detained-asylum-seekers2009-2010.pdf (accessed on 11 June 2013).

30. Detention Watch Network. "Community-Based Alternatives to Immigration Detention." August 2010. Available online: http:/www.detentionwatchnetwork.org/sites/detentionwatchnetwork.org/ files/DWN\%20ATD\%20Report\%20FINAL_08-25-2010.pdf (accessed on 11 June 2013). This figure was calculated using ICE Assistant Secretary John Morton's estimate that the use of detention facilities costs taxpayers on average $\$ 122$ per detained individual per day, as cited in Community-Based Alternatives to Immigration Detention, multiplied by figures provided in ICE's Detained Asylum Seekers: FY2009 and 2010 Report to Congress for the number of asylum seekers detained in FY2010 (separated by category) and the average number of days asylum seekers were detained (separated by category).

31. UNHCR Department of International Protection. "Resettlement Handbook." Geneva: UNHCR, 2004. Available online: http://www.unhcr.org/refworld/pdfid/3ae6b35e0.pdf (accessed on 28 July 2012).

32. UN General Assembly. "International Solidarity and Burden-Sharing in all its Aspects: National, Regional and International Responsibilities for Refugees." Executive Committee of the High Commissioner's Programme, 49th Session. 7 September 1998, A/AC.96/904. Available online: http://www.unhcr.org/cgi-bin/texis/vtx/home/opendocPDFViewer.html?docid=3ae68d978 (accessed on 23 July 2012). The UN details the burden sharing necessary in national, regional and international responsibility for refugees.

33. UNHCR. "Frequently Asked Questions about Resettlement." April 2012, 2. Available online: http://www.unhcr.org/4ac0873d6.html (accessed on 10 August 2012). UNHCR provides a list of the current countries with resettlement programs.

34. U.S. Committee for Refugees and Immigrants. "Warehoused Refugee Populations." World Refugee Survey, 2009, 26-27. Available online: http://www.uscrirefugees.org/ 2010Website/5_Resources/5_5_Refugee_Warehousing/5_5_4_Archived_World_Refugee_Surve ys/5_5_4_7_World_Refugee_Survey_2009/5_5_4_7_1_Statistics/Warehoused_Refugee_Populat ions.pdf (accessed on 11 June 2013). 
35. As of 20 June 2013, there were 1.6 million Syrian refugees. "World Refugee Day: A time to rally round family and friends." UNHCR, 20 June 2013. Available online: http://www.unhcr.org/51c2f6886.html (accessed on 21 June 2013).

36. See ([4], p. 12). UNHCR defines a protracted situation as one in which more 25,000 or more refugees of the same nationality have been in exile for five years or longer in a given asylum county.

37. UNHCR. The State of the World's Refugees 2000: Fifty Years of Humanitarian Action. Edited by Mark Cutts. Oxford: Oxford University Press, 2000, 158. Available online: http://www.unhcr.org/4a4c754a9.html (accessed on 23 July 2012). Citing UNHCR: The State of the World's Refugees: In Search of Solutions. Oxford: Oxford University Press, 1995, 199.

38. UNHCR. The State of the World's Refugees: In Search of Solutions. Oxford: Oxford University Press, 1995, 199.

39. UNHCR. "Funding UNHCR's Programmes." In UNHCR Global Report 2012. 2013, 96. Available online: http://www.unhcr.org/51b1d6210.html (accessed on 21 June 2013).

40. UN General Assembly, 49th Session. Supp. No. 12. 1994 (A/49/12): Table 1. Official Record.

41. UN General Assembly, 51st Session. Supp. No. 12. 1996 (A/51/12): 82 \& 169, Table 1. Official Record.

42. U.S. Department of Homeland Security, Immigration and Customs Enforcement. "Fact Sheet: ICE Fiscal Year (FY) 2012 Enacted Budget." 2011. Available online: http://www.ice.gov/news/library/factsheets/budget-fy2012.htm (accessed on 16 August 2012).

43. Refugee Council of Australia. "2013-14 Federal Budget in Brief: What it Means for Refugees and People Seeking Humanitarian Protection." n.d., 2. Available online: http://www.refugeecouncil.org.au/r/bud/2013-14-Budget.pdf (accessed on 17 June 2013).

44. Delphine Nakache. "The Human and Financial Cost of Detention of Asylum-Seekers in Canada." 2011, 41. Available online: http://www.socialsciences.uottawa.ca/sites/default/files/ public/dvm/eng/documents/dnakache-finalreport-december2011.pdf (accessed on 17 June 2013).

45. UNHCR. "Population, Refugees and the Millennium Development Goals: A UNHCR Perspective." n.d., 3. Available online: http:/www.un.org/esa/population/publications/ PopAspectsMDG/15_UNHCR.pdf (accessed on 20 June 2013).

46. UN Development Fund for Women ("UNIFEM"). "Progress of the World's Women 2008/2009." n.d., 72-73. Available online: http://www.unifem.org/progress/2008/ (accessed on 23 July 2012). UNIFEM displays the trends of social and economic discrimination against refugee women.

47. Bart de Bruijn. "Millennium Development Goals Analysis of Peoples to the Concern of UNHCR." The Hague: Netherlands Interdisciplinary Demographic Institute, 2006. Available online: http://www.unhcr.org/45adedde2.pdf (accessed on 20 June 2013).

48. The United Nations Millennium Campaign, and Office of the UN High Commissioner for Human Rights. "The Millennium Development Goals and Human Rights." Geneva: Office of the UN High Commissioner for Human Rights, n.d., 16. Available online: http://www.unkampagne.de/fileadmin/downloads/news3/final_human_rights_and_mdgs_brochure.pdf (accessed on 21 June 2013). "The MDGs explicitly focus on three marginalized groups-children, slum-dwellers and youth-but others including ... refugees and internally displaced people will also require special focus depending on the context. Moreover, targets should be adapted and disaggregated to ensure the rights of marginalized groups are given sufficient attention in practice." 
49. "Although none of the eight current MDGs deals specifically with refugees, most, if not all, have direct relevance to their plight." ([45], p. 3).

50. UNHCR. Handbook for the Protection of Women and Girls. Geneva: UNHCR, 2008, 113-14. Available online: http://www.refworld.org/docid/47cfc2962.html (accessed on 20 June 2013).

51. UNHCR. "Sexual and Gender-Based Violence against Refugees, Returnees and Internally Displaced Persons: Guidelines for Prevention and Response." May 2003, 43. Available online: http://www.unhcr.org/3f696bcc4.html (accessed on 20 June 2013). "When only male heads of households are registered and issued ration cards, women may be forced to remain in abusive relationships for fear of losing access to food and other assistance. It is therefore essential to register refugees individually and to provide every individual with the appropriate, individual registration cards. When it is not possible to provide separate documents to each family member, adult women should be given high priority for receiving the documents needed to establish eligibility for assistance."

52. Women's Commission for Refugee Women and Children. Displaced Women and Girls at Risk: Risk Factors, Protection Solutions and Resource Tools. New York: Women's Commission for Refugee Women and Children, 2006, 10-11. Available online: http://reliefweb.int/sites/reliefweb.int/files/resources/DF67C6D0045ABAEEC1257129005C5929 -Displaced\%20Women.pdf (accessed on 23 August 2012). "Displaced women are often less likely to possess identity documents than are men, which can create structural impediments to accessing government services. Registration and distribution systems are frequently based on household cards listed under the name of the male head of household - thereby limiting women's access to assistance, especially in cases of separation."

53. John R. Mills, Kristen Echemendia, and Stephen Yale-Loehr. "'Death is Different' and a Refugee's Right to Counsel." Cornell International Law Journal 42 (2009): 361-86. The article discusses the difficulties that arise for refugees in legal proceedings in the U.S. due to a lack of a recognized constitutional right to an attorney for immigration proceedings.

54. Stephen H. Legomsky. "Learning to Live with Unequal Justice: Asylum and the Limits to Consistency." Stanford Law Review 60, no. 2 (2007): 413-74. Legomsky analyzes the limited right to counsel in asylum proceedings and the impact of counsel for refugees in those proceedings.

55. UN General Assembly. "Declaration on the Elimination of Violence Against Women." 48th Session. 85th Plenary Meeting, 20 December 1993, A/RES/48/104. Official Record. The UN provides a definition for 'violence against women'.

56. UNHCR defines the numerous forms of gender-based violence recognized by the UNHCR and the impact of that violence on refugees ([51], pp. 15-26).

57. See Karen Musalo, Jennifer Moore, and Richard Boswell. Refugee Law and Policy, 3rd ed. Durham: Carolina Academic Press, 2011, p. 689.

58. Alexandra Stiglmayer, Marion Faber, Cynthia Enloe, and Roy Gutman. Mass Rape: The War Against Women in Bosnia-Herzegovina. Lincoln: University of Nebraska Press, 1994, 85, 86, 198.

59. Inter-Agency Standing Committee. Guidelines for Gender-based Violence Interventions in Humanitarian Settings. Geneva: Inter-Agency Standing Committee, 2005, 4. Available online: http://www.unhcr.org/453492294.html (accessed on 17 June 2013). 
60. Human Rights Watch. "Sexual Violence and its Consequences among Displaced Persons in Darfur and Chad." 12 April 2005, 2. Available online: http://www.cmi.no/sudan/doc/?id=1069 (accessed on 17 June 2013).

61. UNHCR charts the types of violence most often experienced throughout the phases of the refugee cycle, during which "[w]omen and children face the additional risks of being subjected to sexual and gender-based violence when fleeing the fighting and seeking asylum. Family members are often dispersed during flight, leaving children separated from the rest of their families and women as solely responsible for protecting and maintaining their households." ([51], p. 20).

62. Jane Freedman. "Protecting Women Asylum Seekers and Refugees: From International Norms to National Protection?" International Migration 48 (2010): 175-98.

63. Boston University School of Law's Asylum and Human Rights Clinic has represented many refugee women who were either forced into sex by men along their route to safety, or who agreed to pay smugglers to take them to safety, but were raped or trafficked by them instead.

64. University of California, Hastings College of Law's Center for Gender \& Refugee Studies tracks and provides assistance to multiple women in Haiti who are forced into sexual relationships in order to pay for food and school tuition. University of California, Hastings College of the Law, Center for Gender \& Refugee Studies. Two-Years after the Earthquake: Combating GenderBased Violence in Haiti-New Reports. 2012. Available online: http://cgrs.uchastings.edu/pdfs/ Haiti_Newsletter_January\%202012.pdf (accessed on 3 October 2012).

65. Columbia Law School's Sexuality and Gender Law Clinic has provided third-party intervention in human trafficking cases to draw countries' attention to the magnitude of the international gender discrimination problem. See Columbia Law School-Clinical Education-Sexuality and Gender Law Clinic: Trafficking and Forced Labor. Available online: http://www.law.columbia.edu/sexuality-gender-law-clinic/issues/trafficking (accessed on 3 October 2012).

66. The Clinic further concluded in a brief to the European Court of Human Rights that "sex trafficking is a form of slavery, and that its victims should be treated accordingly." Columbia Law School Sexuality and Gender Law Clinic. Third Party Intervention. Available online: http://www.law.columbia.edu/null/download?\&exclusive=filemgr.download\&file_id=164288 (accessed on 3 October 2012).

67. United States Department of State. "Trafficking in Persons Report 2010 - Syria." 14 June 2010. Available online: http://www.unhcr.org/refworld/docid/4c1883c12f.html (accessed on 24 July 2012).

68. Ruth Sherlock, and Carol Malouf. "Syrian Girls 'Sold' into Forced Marriages." The Telegraph, 23 January 2013. Available online: http:/www.telegraph.co.uk/news/worldnews/middleeast/ syria/9821946/Syrian-girls-sold-into-forced-marriages.html (accessed on 20 June 2013).

69. UN Women. "Facts \& Figures on Violence Against Women." Available online: http://www.unifem.org/gender_issues/violence_against_women/facts_figures.php (accessed on 13 August 2012).

70. Women's Commission for Refugee Women \& Children. "Women, Children and Youth in the Iraq Crises: A Fact Sheet." January 2008. Available online: http://www.rhrc.org/resources/ Iraqi_women_girls_factsheet\%20FINAL\%20JAn08.pdf (accessed on 13 August 2012). 
71. UNHCR. "Combatting Human Trafficking: Overview of UNHCR Anti-Trafficking Activities in Europe." December 2005, 7. Available online: http://www.unhcr.org/refworld/pdfid/ 43fd782d4.pdf (accessed on 23 August 2012).

72. Human Rights Watch. "Jailing Refugees." 29 December 2009. Available online: http://www.hrw.org/en/node/87369/section/2 (accessed on 10 August 2012). Human Rights Watch describes the detention policies of the U.S. towards refugees who do not promptly and correctly file for asylum and offering proposed changes to the current laws.

73. See also Lisa Anderson. "TrustLaw Poll-Afghanistan is Most Dangerous Country for Women." 15 June 2011. Available online: http:/www.trust.org/item/?map=trustlaw-poll-afghanistan-ismost-dangerous-country-for-women/ (accessed on 29 August 2013). TrustLaw details the results of a poll of global experts in order to determine the various factors and risks that lead to dangerous environments for women.

74. Amber Peterman, Tia Palermo, and Caryn Bredenkamp. "Estimates and Determinants of Sexual Violence Against Women in the Democratic Republic of Congo." American Journal of Public Health 101, no. 6 (2011): 1064.

75. See Physicians for Human Rights, and Harvard Humanitarian Initiative. Nowhere to Turn: Failure to Protect, Support, and Assure Justice for Darfuri Women. Cambridge: Physicians for Human Rights, 2009. Available online: https://s3.amazonaws.com/PHR_Reports/nowhere-toturn.pdf (accessed on 11 August 2012).

76. See also "Women, Poverty \& Economics." Gender Issues, UNIFEM. Available online: $\mathrm{http} / /$ www.unifem.org/gender_issues/women_poverty_economics (accessed on 11 August 2012). UNIFEM notes that women face particular hardships in employment equality, as shown by a 17\% average wage gap between men and women in 2008 .

77. Dept. of Economic and Social Affairs, Division for the Advancement of Women. 2009 World Survey on the Role of Women in Development: Women's Control over Economic Resources and Access to Financial Resources, Including Microfinance. New York: United Nations, 2009, 48-49. Available online: http://www.un.org/womenwatch/daw/public/WorldSurvey2009.pdf (accessed on 13 August 2012). The UN generally notes the barriers women face in accessing land, housing, employment, social protection and financial resources, and specifically highlights how women's transportation limitations effects their ability to earn an income and to access education and medical care.

78. Human Rights Watch. "Welcome to Kenya." 2010, §VI. Available online: http://www.hrw.org/en/node/90848/section/11 (accessed on 13 August 2012). Human Rights Watch describes the restrictions on movement for refugees in Kenya, the requirements for passes to move from one place to another and the barriers to obtaining passes.

79. United Nations Children's Fund ("UNICEF”). Soap Stories and Toilet Tales. New York: UNICEF, n.d., 12. Available online: http://www.unicef.org/wash/files/Soap_Stories_and_ Toilet_Tales.pdf (accessed on 21 June 2013).

80. Education for All ("EFA") Global Monitoring Report Team. EFA Global Monitoring Report 2012: Youth and Skills: Putting Education to Work. Paris: United Nations Educational, Scientific and Cultural Organization (“UNESCO”), 2012, 2. Available online: http://unesdoc.unesco.org/ images/0021/002180/218003e.pdf (accessed on 20 May 2013). 
81. "Children working in domestic services, usually girls or children working and/or living on the street ('street children'), may be particularly at risk of sexual abuse and exploitation." See, ([51], p. 73).

82. The Women's Commission notes that "[d]isplaced girls also work as domestic workers in urban centers, in refugee camps and in neighboring host communities. Children in such circumstances are vulnerable to mistreatment, including the withholding of payment and physical and sexual abuse" ([52], p. 16). The report also cites an interview with a 15-year-old Congolese girl in Tongagara camp, Zimbabwe, describing her employer's demands for sex: "[h]e told me if I wanted a scholarship [for secondary school], I had to be his girlfriend. I had to have sex with him. Other girls did it. They wanted to go to school. I refused and didn't get my scholarship" ([52], p. 9).

83. See ([51], p. 40). UNHCR notes the prevalence of female refugees who become separated from their husbands and male family members and the non-traditional role that women must assume.

84. See Maja Korac. "War, Flight, and Exile: Gendered Violence Among Refugee Women from Post Yugoslav States." In Sites of Violence: Gender and Conflict Zones, edited by Wenona Giles, and Jennifer Hyndman. Berkeley: University of California Press, 2004, pp. 249-72. Available online: http://roar.uel.ac.uk/jspui/bitstream/10552/669/1/Korac\%2c\%20M\%20\%282004\%29\%20Sites\% 20of\%20Violence\%20pp\%20249-72.pdf (accessed on 24 August 2012). (Korac provides a refugee woman's description of feeling incompetent and helpless while trying to raise her children alone).

85. See also ([50], p. 11). UNHCR describes the additional plight of girls who become caregivers for parents who cannot speak the new language.

86. UN Dept. of Public Information. "Goal 2: Achieve Universal Primary Education." 2010. Available online: http://www.un.org/millenniumgoals/pdf/MDG_FS_2_EN.pdf (accessed on 16 August 2012). The article indicates that in developing regions there are 96 girls for every 100 boys enrolled in primary education and 95 girls for every 100 boys in secondary education, but still only an average of 67-76 girls for every 100 boys enrolled in tertiary education.

87. Michael Kagan. "Is Truth in the Eye of the Beholder? Objective Credibility Assessment in Refugee Status Determination." Georgetown Immigration Law Journal 17 (2003): 367-415. Kagan discusses the factors that contribute to a credibility assessment in refugee and asylum cases, and the importance of that assessment to success in the case.

88. See Refugee Appeal No. 915/92 Re SY (29 August 1994) (Austral). The court finds that an applicant was not credible because the account of prior sexual abuse that she gave at the airport was less inclusive then a previously recorded description of events; however, the airport interview was conducted after the applicant, who was menstruating, was strip searched, leading to severe embarrassment.

89. See Gauri van Gulik. "Women, Asylum and the UK Border Agency." Human Rights Watch, 2010. Available online: http://www.hrw.org/news/2010/03/02/women-asylum-and-uk-borderagency (accessed on 16 August 2012). van Gulik describes how the UK's 'fast track' asylum process works against finding credibility because women have insufficient time to build a trusting relationship with advocates. 
90. But see Federal Court of Australia. "Hermiz v Minister for Immigration \& Multicultural Affairs [1999] FCA 1737." 17 December 1999, 13 (Austral). Available online: http://www.austlii.edu.au/au/cases/cth/FCA/1999/1737.html (accessed on 29 August 2013). The court acknowledges "that various barriers may exist such as language and cultural differences which can affect [an applicant's] ability to provide a coherent, consistent and plausible account."

91. Immigration and Refugee Board of Canada. "Guidelines Issued by the Chairperson Pursuant to Section 65(3) of the Immigration Act: Women Refugee Claimants Fearing Gender-Related Persecution." 13 March 1996. Available online: http://www.irb-cisr.gc.ca/Eng/BoaCom/ references/pol/GuiDir/Pages/GuideDir04.aspx (accessed on 28 August 2013).

92. The Asylum and Human Rights program at Boston University School of Law is not unique in representing women asylum-seekers who, after being required to give details of their experiences to the court, have then been rejected and sometimes abandoned by their spouses.

93. UNHCR. "Procedural Standards for Refugee Status Determination under UNHCR's Mandate." 2003. Available online: http://www.unhcr.org/4317223c9.pdf (accessed on 23 August 2012). UNHCR establishes the standards for registering and processing refugee status determination claims, which highlight the importance of status as a 'principal applicant.'

94. "Women and girls may be viewed as dependants without rights or claims in their own right." ([50], p. 17).

95. UNHCR notes that women and girls "can often represent the best way to ensure assistance reaches the whole family." ([50], p. 17).

96. See Shoafera v. INS, 228 F.3d 1070, 1079 (9th Cir. 2000). The 9th Circuit reverses the Board of Immigration Appeals (BIA) and the immigration judge's (IJ) decisions that had found that the applicant was raped not because of her ethnicity, but because her rapist was "a man who believed he had the authority and impunity to carry out sexual depravities."

97. Gomez v. INS, 947 F.2d 660, 664 (2d Cir. 1991). The 2nd Circuit holds that beatings and rapes of applicant when she was between 12 and 14 years old were not considered persecution 'on account of' social group membership.

98. Campos-Guardado v. INS, 809 F.2d 285, 290 (5th Cir. 1987). The 5th Circuit finds petitioner ineligible for asylum: the rapes she suffered were not persecution because they were not 'on account of' her political opinion or membership in a particular social group.

99. But see a minority line of cases beginning with In re D- V-, 21 I. \& N. Dec. 77 (BIA 1993), where the BIA found that a female applicant was raped 'on account of' her political opinion and held that persecution occurred.

100. UNHCR's 1991 Guidelines on Refugee Women summarized the state of the law at the time: "[V]ictims of rape by military forces face difficulties in obtaining refugee status when the adjudicators of their refugee claim view such attacks as a 'normal' part of warfare." UNHCR. Guidelines on the Protection of Refugee Women. Geneva: UNHCR, 1991. Available online: http://www.unhcr.org/refworld/docid/3ae6b3310.html (accessed on 5 August 2012).

101. See also Heaven Crawley, and Trine Lester. Comparative Analysis of Gender-Related Persecution in National Asylum Legislation and Practice in Europe. Geneva: UNHCR Evaluation and Policy Analysis Unit, 2004. Available online: http://www.jrseurope.org/ 
accompanydetainees/docs/Crawley\%20Report\%20on\%20EU\%20Gender\%20and\%20Asylum.pdf (accessed on 5 August 2012).

102. Refugee Women's Resource Project. "Leave Granted to Woman Who Lost at Every Appeal Stage." Women's Asylum News, May 2003. Issue 32, pp. 1-2. Available online: http://www.unhcr.org/refworld/pdfid/47b17597d.pdf (accessed on 21 June 2013). The article discusses a UK Court of Appeal decision to deny Convention protection from persecution to a Ugandan woman who was repeatedly raped on account of her son's political affiliations.

103. Karen Musalo. "Protecting Victims of Gendered Persecution: Fear of Floodgates or Call to (Principled) Action?" Virginia Journal of Social Policy \& Law 14 (2007): 119-58. Musalo notes that under Guatemalan law, "[s]pousal rape is also not recognized as a crime, and a man who rapes a woman who is not his wife is released from criminal culpability if he marries his victim as long as she is twelve years of age or older."

104. See In re A- T-, 24 I. \& N. Dec. 296, 301 (BIA 2007) (The case demonstrates the position, before it was overruled, of the BIA's refusal to recognize FGM as persecution.), vacated, In re A- T-, 24 I. \& N. Dec. 617 (BIA 2008).

105. More recently, there has been slow progress in the U.S. in recognizing FGM as a basis for future persecution. See, e.g., Bah v. Mukasey, 529 F.3d 99, 112 (2d Cir. 2008). The 2nd Circuit reasons that FGM can be a source of ongoing fear of persecution and, as such, can be grounds for asylum.

106. Crawley states Swedish law that "cases based on a fear of FGM cannot result in refugee status." ([101], p. 58).

107. Stefan Ericsson. "Working Paper of the Directorate-General for Research of the European Parliament on Asylum in the EU Member States." LIBE 108 EN, 2000, 92. Available online: http://www.europarl.europa.eu/workingpapers/libe/pdf/108_en.pdf (accessed on 26 August 2012). Ericsson explains that Greece has begun to take FGM into account during decisionmaking, but this type of gender-related persecution has rarely been sufficient to afford protection.

108. Rodger PG Haines. "Gender-Based Persecution: New Zealand Jurisprudence.” February 1996, 30. Available online: http://www.refugee.org.nz/Gennz.htm\#THE\%20NEW\%20ZEALAND\% 20REFUGEE\%20DETERMINATION\%20PROCESS (accessed on 26 August 2012). Haines states that "some Western countries, especially Germany, Sweden and France, []restrict[] the application of the concept of agents of persecution to the extent that refugee status is only granted to victims of persecution by state authorities or by other actors encouraged or tolerated by the state."

109. See Minister for Immigration and Multicultural Affairs v. Khawar, (2002) 76 A.L.J.R. 667, 120 (Austral.) (The court states that the husband and his family member's motivation for abusing and threatening the petitioner was not related to her membership in a gender-specific social group.).

110. Crawley describes a Swedish case where "a Bangladeshi woman whose account of gang rape by political opponents was considered credible but not to be for a Convention reason or sufficiently serious to warrant the granting of refugee status.... [N]o woman who had suffered rape at the hands of non-State agents was granted refugee status."). ([101], p. 38).

111. Karen Musalo. "Revisiting Social Group and Nexus in Gender Asylum Claims: A Unifying Rationale for Evolving Jurisprudence.” DePaul Law Review 52 (2003): 777. Musalo analyzes the progression from the routine failure of many courts to recognize a range of different types of 
individual abuse of women as grounds for asylum to multiple international courts accepting their validity for asylum claims.

112. See UNHCR. "Guidelines on International Protection: Gender-Related Persecution within the Context of Article 1A(2) of the 1951 Convention and/or its 1967 Protocol Relating to the Status of Refugees." 7 May 2002, HCR/GIP/02/01, 7. Available online: http://www.unhcr.org/ refworld/docid/3d36flc64.html (accessed on 10 August 2012).

113. US Citizenship and Immigration Services, Asylum Division. "Asylum Officer Basic Training: Female Asylum Applicants and Gender-Related Claims." 12 March 2009. Available online: http://www.uscis.gov/USCIS/Humanitarian/Refugees\%20\&\%20Asylum/Asylum/AOBTC\%20Le sson\%20Plans/Female-Asylum-Applicants-Gender-Related-Claims-31aug10.pdf (accessed on 16 August 2012).

114. See also Leah Bassel. "Citizenship as Interpellation: Refugee Women and the State, Government and Opposition." Government and Opposition 43 (2008): 2. Available online: http://onlinelibrary.wiley.com/doi/10.1111/j.1477-7053.2007.00247.x/full (accessed on 25 July 2012).

115. See Executive Committee of the High Commissioner's Programme, UN High Commissioner for Refugees. "Refugee Women and International Protection." 18 October 1985, No. 39. Available online: http://www.refworld.org/docid/3ae68c43a8.html (accessed on 21 June 2013). Noting that "women asylum-seekers who face harsh or inhuman treatment due to having transgressed the social mores of the society in which they live may be considered as a "particular social group" within the meaning of Article 1 A(2) of the 1951 United Nations Refugee Convention.

116. Considerations for Asylum Officers Adjudicating Asylum Claims from Women. Memorandum from Phyllis Coven, Office of International Affairs, US INS, to All INS Asylum Officers, 1995.

117. UNHCR acknowledges that "the grounds for establishing refugee status do not include gender." ([112], p. 16).

118. Despite the progress in granting gender-related claims for asylum in many countries, the U.S., along with other countries, does not recognize 'gender' alone as a Convention ground. Gender, in addition to other factors, can be the basis for an asylum claim. See, e.g., In re Kasinga, 21 I. \& N. Dec. 357, 358 (BIA 1996). (The court found that young women of the Tchamba-Kunsuntu Tribe who have not had FGM as practiced by the tribe and who oppose the practice can constitute a particular social group.).

119. See also ([107], p. 107). Ericsson notes that Italy lacks specific provisions related to female refugees, and that courts have occasionally recognized persecution on membership of a social group, but only when women "have transgressed strict religious or social rules."

120. See also ([101], pp. 47, 85). Crawley states that under both Dutch and Swedish law, a social group cannot be defined by gender.

121. See "Summary Conclusions: Gender-Related Persecution." Expert Roundtable Organized by the UNHCR and the International Institute of Humanitarian Law, San Remo, Italy, 6-8 September 2001. Para. 4. "The main problem facing women asylum seekers is the failure of decision makers to... recognize the political nature of seemingly private acts of harm to women."

122. See Carol Bohmer, and Amy Shuman. "Gender \& Political Asylum." Foreign Policy Association, 13 April 2011. Available online: http://foreignpolicyblogs.com/2011/04/13/gender- 
political-asylum/ (accessed on 23 July 2012). Bohmer notes that while political asylum is conceptually gender-neutral, men and women's claims are not evaluated equally in practice; the "evaluation of women's political action is sometimes regarded as either not political enough or as belonging to such a general category that granting political asylum would 'open the floodgates' to too many individuals."

123. See Eithne Luibheid. Entry Denied: Controlling Sexuality at the Border. Minneapolis: University of Minnesota Press, 2002. "[R] ealms of experience that usually belonged to women-including experiences of rape-were foreclosed from consideration...as possible grounds for asylum," or as evidence of persecution.

124. See Heaven Crawley. "Gender, Persecution and the Concept of Politics in the Asylum Determination Process." Forced Migration Review 9 (2000): 17-18. Available online: http://www.fmreview.org/sites/fmr/files/FMRdownloads/en/FMRpdfs/FMR09/fmr9full.pdf (accessed on 2 August 2012). Crawley notes “that the extent of women's political participation has been underestimated...indicat[ing] a tendency to misrepresent gendered forms of persecution and resistance as personal rather than political."

125. See Emily Love. "Equality in Political Asylum Law: For a Legislative Recognition of GenderBased Persecution." Harvard Women's Law Journal 17 (1994): 139. Love highlights that under the definition of refugee, political opinion is viewed as a public sphere activity, invariably shifting the focus of political asylum claims away from women whose activities are typically domestic.

126. Compare the successful claims of male asylum seekers claiming persecution on account of political opinion: Navas v. INS, 217 F.3d 646, 661 (9th Cir. 2000), Ratnam v. INS, 154 F.3d 990, 996 (9th Cir. 1998), and Haider v. Holder, 595 F.3d 276, 285 (6th Cir. 2010), with similar claims by female asylum seekers who ultimately failed: Klawitter v. INS, 970 F.2d 149, 152 (6th Cir. 1992), Campos-Guardado, 809 F.2d at 290, and In re Konesan, A29 637 308, slip op. (BIA June 11, 1992).

127. See also Refugee Appeal No. 2039/93 Re MN (12 February 1996) at 50 (N.Z.) (“An approach to refugee determination which unjustifiably favours the political opinion ground to the exclusion of the social group ground will tend to reinforce the male gender bias often complained of by female asylum-seekers, and inhibit the development of a refugee jurisprudence which properly recognises and accommodates gender issues within the legitimate bounds of the Refugee Convention.").

128. See also ([101], p. 70). Crawley provides two examples of adjudicatory failure to acknowledge women's political activities as significant.

129. See also ([107], p. 82). Ericsson describes that Germany rarely considers gender-related persecution as political.

130. UNHCR highlights the difficulties for women making claims based on political opinion in domestic courts. "The image of a political refugee as someone who is fleeing persecution for his or her direct involvement in political activity does not always correspond to the reality of the experiences of women... Women are less likely than their male counterparts to engage in high profile political activity..." ([112], p. 9).

131. See Refugee Appeal No. 3/91 Re ZWD (20 October 1992) (The court states New Zealand's generally accepted practice that although 'one child' policies, forced sterilization and forced 
abortion are not per se within protected Convention grounds, there may be situations where a sufficient political opinion will qualify the case as persecution.).

132. Crawley notes that German law tends to focus on political persecution, and cases involving FGM and noncompliance with religious dress codes are generally considered under this Convention ground. ([101], p. 87).

133. Women's Refugee Resource Project. Women Asylum Seekers in the UK: A Gender Perspective, Some Facts and Figures. London: Asylum Aid, 2003, pp. 112-13. Available online: http://www.asylumaid.org.uk/data/files/publications/29/Women\%20asylum $\% 20$ seekers $\% 20 \mathrm{in} \% 2$ 0the $\% 20 \mathrm{UK} \% 20 \mathrm{a} \% 20$ gender\%20perspective.pdf (accessed on 2 August 2012). "[D]ress codes may violate a woman's right to freedom of conscience, expression or religion..."

134. UNHCR describes the way in which non-conformity to religious gender norms by a woman can lead to her persecution, even when she remains an adherent of the same religion as the perpetrator of the persecution. ([112], p. 6).

135. But these cases do not fare well in the U.S. and several other states' courts. See, e.g., Fatin v. INS, 12 F.3d 1233 (3d Cir. 1993).

136. See Fisher v. INS, 79 F.3d 955 (9th Cir. 1996).

137. See ([101], p. 45), discussing Finnish law.

138. It has proved especially difficult for women and girls from the Arab and Muslim world to succeed in asylum claims with particular social group arguments. Most courts have interpreted these claims as assertions that the Islamic religion is the source of persecution - that is, that all women fleeing the Muslim world are refugees because Islam itself persecutes women. Although there has been slow progress here too, claims of Muslim women fleeing Muslim countries remain unlikely to succeed on the grounds of particular social group. See Susan M. Akram. "Orientalism Revisited in Asylum and Refugee Claims.” Intl. Jour. Refugee Law 12 (2000): 7, 19. See also Refugee Appeal No. 71427/99,2000 NZAR 545 at 74 (N.Z.). Available online: http://www.unhcr.org/refworld/docid/3ae6b7400.html (accessed on 21 June 2013) ("The 1979 Iranian Constitution does not expressly relegate women to second-class status... However, the cumulative effect of the laws of Iran and of the so-called Islamic form of governance certainly produces that result.").

139. "The cultural relativity argument has the potential of confusing decision-makers in countries of asylum as to the appropriate standard by which human rights infringements in the country of origin are to be judged." ([108], p. 37).

140. Safaie v. INS, 25 F.3d 636 (8th Cir. 1994) superseded by statute as stated in Ngengwe v. Mukasey, 543 F.3d 1029, 1034 (8th Cir. 2008).

141. Ngengwe illustrates "that gender asylum is alive and well in the current decade and continues to improve." T.S. Twibell. "The Development of Gender as a Basis for Asylum in United States Immigration Law and Under the United Nations Refugee Convention: Case Studies of Female Asylum Seekers from Cameroon, Eritrea, Iraq and Somalia." Georgetown Immigration Law Journal 24 (2010): 189. The decision also aids U.S. asylum seekers by countering the stereotype that refugees seek to abuse the system or threaten national security ([141], p. 308).

142. However, establishing a social group's existence is not a per se finding of a nexus relationship between the social group and the persecutor's motive. K. T. Seelinger. "Forced Marriage and 
Asylum: Perceiving the Invisible Harm.” Columbia Human Rights Law Review 42 (2010): 102. Available online: http://www3.law.columbia.edu/hrlr/hrlr_journal/42.1/Seelinger.pdf (accessed on 18 August 2012).

143. INS v. Elias-Zacarias, 502 U.S. 478 (1992).

144. The Supreme Court interpreted the nexus requirement to mean that the victim must prove the intent of the persecutor, and that intent must be a Convention ground. This case concerned the motivation of Guatemalan guerrillas in threatening a young male applicant. ([143], pp. 483-84).

145. UNHCR implicitly criticized the U.S.' restrictive interpretation of the nexus requirement of Elias-Zacarias and the REAL ID Act in its 2002 Gender Guidelines. "The Convention ground must be a relevant contributing factor, though it need not be shown to be the sole, or dominant, cause... Attribution of the Convention ground to the claimant by the State or non-State actor of persecution is sufficient to establish the required causal connection." ([112], p. 6).

146. See also Joan Fitzpatrick. "The International Dimension of U.S. Refugee Law.” Berkeley Journal International Law 15 (1997): 12-24. (Fitzpatrick discusses the Elias-Zacarias decision and its connection with UNHCR guidelines for U.S. refugee law.).

147. U.S. courts' application of the Elias-Zacarias nexus requirement has created a difficult obstacle for refugee rape victims to overcome. See Menendez-Donis v. Ashcroft, 360 F.3d 915, 917 (8th Cir. 2004).

148. See Quirino v. INS, 254 F.3d 859, 863 (9th Cir. 2001).

149. See Molina-Morales v. INS, 237 F.3d 1048 (9th Cir. 2001).

150. See Basova v. INS, INS No. A73 736650 (10th Cir. July 14, 1999) (unpublished disposition). Available online: http://caselaw.lp.findlaw.com/scripts/getcase.pl?navby=search\&case $=/$ data2/circs/10th/989540.html (accessed on 21 June 2013).

151. However, even before the Court decided Elias-Zacarias, lower courts were cognizant of female refugee's plight in making an asylum claim based on rape as persecution. See, e.g., BolanosHernandez v. INS, 767 F.2d 1277, 1285 (9th Cir. 1984) ("Persecutors are hardly likely to provide their victims with affidavits attesting to their acts of persecution.").

152. See In re D-V-, 21 I. \& N. Dec. at 77 (The initial denial by both the IJ and the BIA was based on the BIA's position that the female applicant could not satisfy the nexus requirement as interpreted by the Supreme Court in Elias-Zacarias.).

153. See also Campos-Guardado, 809 F.2d at 289.

154. See also Melgar de Torres v. Reno, 191 F.3d 307, 313 (2d Cir. 1999).

155. UN. "Goal 1: Eradicate Extreme Poverty \& Hunger." Available online: http://www.un.org/ millenniumgoals/poverty.shtml (accessed on 20 June 2013).

156. UN. "Goal 13: Promote Gender Equality and Empower Women." Available online: http://www.un.org/millenniumgoals/gender.shtml (accessed on 20 June 2013).

157. The World Bank. "Twenty Fragile States Make Progress on Millennium Development Goals." 1 May 2013. Available online: http://www.worldbank.org/en/news/press-release/2013/05/01/ twenty-fragile-states-make-progress-on-millennium-development-goals (accessed on 20 May 2013).

158. Women Watch. "Facts \& Figures: Rural Women and the Millennium Development Goals." Available online: http://www.un.org/womenwatch/feature/ruralwomen/facts-figures.html (accessed on 21 May 2013). 
159. See, e.g., United Nations Development Group. "The Global Conversation Begins: Emerging Views for a New Development Agenda." 2013. Available online: http://www.worldwewant2015.org/the-global-conversation-begins (accessed on 28 August 2013).

160. See also UN System Task Team on the Post-2015 UN Development Agenda. "A Renewed Global Partnership for Development." New York, March 2013. Available online: http://sustainabledevelopment.un.org/content/documents/833glob_dev_rep_2013.pdf (accessed on 28 August 2013).

161. Global Thematic Consultation on Population Dynamics. "Population Dynamics in the Post-2015 Development Agenda.” 25 April 2013. Available online: http://www.iom.int/files/live/sites/iom/ files/What-We-Do/docs/Outcome-Report-Pop-dynamic-and-post-2015-dev-agenda-14-March2013.pdf (accessed on 28 August 2013).

162. Kathleen Newland. "Concept Paper for the High-Level Panel Expert Policy Dialogue on Migration in the Post-2015 Development Agenda.” 18 February 2013. Available online: http://blogg.ud.se/utvecklingspolitik/files/2013/03/Concept-paper-for-the-high-level-panelexpert-policy-dialogue-on-migration.pdf (accessed on 28 August 2013).

163. See ([162], p. 5) "It seems unlikely that one among the very small number of post-2015 development goals will be entirely devoted to migration."

(C) 2013 by the author; licensee MDPI, Basel, Switzerland. This article is an open access article distributed under the terms and conditions of the Creative Commons Attribution license (http://creativecommons.org/licenses/by/3.0/). 